\title{
Early Pliocene paleoceanography of the Vityaz Fracture Zone, Central Indian Ridge
}

\author{
M. V. S. Guptha ${ }^{1 *}$, Ranadip Banerjee ${ }^{1 * *}$, Lina P. Mergulhao ${ }^{1}$, Priyanka \\ Banerjee $^{2}$, G. Parthiban ${ }^{1}$, Manish Tewari ${ }^{3}$ \\ ${ }^{1}$ National Institute of Oceanography, Dona Paula, Goa-403 004, India \\ ${ }^{2}$ Department of Geological Sciences, Jadavpur University, Kolkata, 700032, \\ India \\ ${ }^{3}$ Physical Research Laboratory, Navrangpura, Ahmedabad, India
}

\begin{abstract}
:
Planktic foraminifera from the calcareous substrate of a ferromanganese crust from the Vityaz Fracture Zone (VFZ), Central Indian Ridge were studied to reconstruct the early Pliocene paleoceanography of this region. Eleven species of foraminifera were encountered, among them Globorotalia menardii, Neogloboquadrina dutertrei, Globigerina bulloides and Globigerinoides ruber are prominent. Predominance of $N$. dutertrei in the top $3 \mathrm{~cm}$ of the carbonate substrate is attributed to the influx of fresh water which eventually triggered the productivity by increasing nutrient level. The presence of G. bulloides and G. menardii in significant proportions in deeper layers suggests the prevalence of open ocean upwelling. The bulk chemical composition of the substrate at different depth intervals indicated higher enrichment of trace metals in the upper sections which could have been supplied through oceanic water by the chemical weathering of terrestrial matter during the peak of the Pliocene Asian monsoon. Thus, it was concluded that during the early Pliocene the biogenic components of the substrate were distinctly contributed by both the upwelling and productivity triggered by a fresh water influx originated through the intensification of the Asian monsoon during the early Pliocene Period.

Keywords: Central Indian Ridge, Vityaz Fracture Zone, Ferromanganese crust, Biogenic loom, Freshwater influx, Neogene, Spores, Asian monsoon $* * * * * * * * * * * * * * * * * * * * * * * * * * * * * * * * * * * * * * * * * * * * * * * * * * * * * * * * * * * * * * * * * * * * * * * * * * * * * *$

* Present address: 62, Sagar Society, Dona Paula (Goa)-403 004, India

** Corresponding author (e-mail: ocean1@rediffmail.com)
\end{abstract}




\section{Introduction}

It was Emiliani's (1955) pioneering work that led to the emergence of Paleoceanography, as one of the most important fields of marine geology. Later, the advent of the Deep Sea Drilling Program (DSDP), enabled researchers to unravel the intricacies of changes in nature and composition of sediment and associated huge amount of microfossils which would facilitate in the re-construction of paleoceanography. Further investigations on micropaleontological, geochemical and sedimentological aspects helped in resolving and understanding meaningfully the conspicuous fluctuations in calcium carbonate and its implication for ocean circulation patterns in the geological past.

Many significant paleoclimatic and paleoceanographic changes occurred during the Neogene in the Indian Ocean. Several studies carried out on the Neogene paleoproductivity in the Indian and Pacific Oceans which emerged into a hypothesis known as the "biogenic bloom" hypothesis (Farrell et al., 1995a). Like in the Pacific Ocean during the latest Miocene and Pliocene, several investigations carried out in the northern Indian Ocean have also documented similar lithological, biological and chemical variations during the latest Miocene and Pliocene sediments (Peterson and Backman, 1990; Peterson et al., 1992; Brummer and Van Eijden, 1992; Dickens and Owen, 1994; Siesser, 1995). Extensive studies carried out by various researchers (Peterson et al., 1992; Berger et al., 1993; Delaney and Fillippelli, 1994; Dickens and Owen, 1994, 1996; Farrell et al., 1995a,b; Rea et al., 1995; Guptha et al., 2002) have inferred the occurrence of increased productivity during this time preserved in the sediments of the Indo-Pacific upwelling regions.

Differential heating of the continental and oceanic regions during summer seasons results in low atmospheric pressure above the Asian Plateau and high atmospheric pressure over the southern Indian Ocean. This pressure gradient between the low pressure zone over the southern Indian Ocean drives high velocity winds in a southwest to northeast direction Smith et al., (1991). The seasonal occurrence of upwelling system in the Indian Ocean is driven by the intense atmospheric phenomenon resulting in the southwest monsoon which reaches its peak during summer season (Wyrtiki 1971, Prell and Streeter 1982).

Most of the regions in the western Indian Ocean are characterized by upwelling of nutrient-rich deep waters into the nutrient-poor euphotic zone supporting the "biogenic bloom" hypothesis. Beaufort (1997) reported that over the past $900 \mathrm{kyr}$, productivity in the tropical Indian Ocean may have been linked to the intensity of westerly winds related to the Southern Oscillation. The monsoon system in the Indian Ocean became more vigorous with the upliftment of Himalayas (Raymo and Ruddiman, 1992; Kutzbach et al., 1993) since the late Miocene (Prell wt al., 1991; Molnar et al., 1992; Filipelli, 1997). Consequently, the high surface productivity at these Indo- 
Pacific divergence zones result in sinking of enormous amount of organic matter in the water column facilitating the development of an oxygen minimum zone (OMZ) in the intermediate water depths of the present day Indo-Pacific divergence zones (Wyrtki, 1971). Guptha et al., (2002) reported the occurrence of dissolution as evidenced by the presence of Uvigerina, Lenticulina, Bulimina, and Bolivina indicating the infringement of OMZ.

According to Dickens and Owen (1999), the "biogenic bloom" hypothesis for the Indian Ocean suggests that during the latest Miocene to early Pliocene, the primary productivity significantly increased which was associated with the intensification of OMZ. Recently, Hermoyian and Owen (2001) based on their study on phosphorus accumulation rate in sediment cores from the Indian Ocean also supported this paleoceanographic event and suggested the prevalence of a high productivity around 4-5.5 Ma, substantiating the Indo-Pacific bloom hypothesis. Earlier, Gupta and Thomas (1999) suggested that the initiation of the Asian monsoon and the development of poorly ventilated, intermediate to deep waters caused the biogenic bloom in the northwestern Indian Ocean during the late Miocene to early Pliocene. Guptha et al., (2002) reported the occurrence of dissolution as evidenced by the presence of Uvigerina, Lenticulina, Bulimina, and Bolivina indicating the infringement of OMZ.

Planktic foraminifera being very sensitive, readily respond to any changes that occur in hydrography of the euphotic zone and also act as proxies of sea surface temperature, upwelling and productivity. Therefore, we chose to study their detailed distributional pattern at all the intervals of calcareous substrate. Using this information, an attempt has been made in the present study to understand the role of paleoceanographic processes responsible for the biological productivity during the early Pliocene Period at the Vityaz Fracture Zone (VFZ) in the Central Indian Ridge, western Indian Ocean.

\section{Methodolgy}

As part of the InRidge Program, a ferromanganese crust with a carbonate substrate was collected by dredging in the VFZ area (longitude $67^{\circ} 53.40^{\prime} \mathrm{E}$; latitude $5^{\circ} 33.90^{\prime} \mathrm{S}$ ) at a water depth of 3,500 $\mathrm{m}$ (Fig. 1). The 15-cm-thick carbonate substrate was white to buff in color overlain by approximately $5 \mathrm{~cm}$ of ferromanganese oxides. The substrate was sub sampled from surface to $3-\mathrm{cm}$, and then at every $2-\mathrm{cm}$ interval from 3 to $15 \mathrm{~cm}$. For detailed micropaleontological analysis, the samples were soaked in distilled water overnight to which sodium hexametaphosphate was added. And then wet sieved through an ASTM 230 mesh sieve $(63 \mu \mathrm{m})$ to separate the coarse and fine fractions and oven dried at $50^{\circ} \mathrm{C}$. The oven dried samples were further sieved through $150 \mu \mathrm{m}$ and the $+150 \mu \mathrm{m}$ fraction and examined under the Leitz polarizing binocular microscope. The associated coarse fraction and plant and fungal (?) spores were examined using SEM 
(JEOL-JSM5800 LV). The plant and fungal (?) spores were determined by counting them from 20 fields of view at a magnification of x3,500. $\delta 18 \mathrm{O}$ of all the samples were measured by mass spectrometry at the Physical Research Laboratory, Ahmedabad, using specimens of Globorotallia menardii as this was the only species consistently distributed through out the substrate. All $\delta 18 \mathrm{O}$ values were calibrated with PDB and the reproducibility of $\delta 180$ was $\pm 0.2 \%$. Bulk geochemical analyses of all seven substrate sections were carried out by using a sequential ICP-OES (Perkin Elmer, OPTIMA 2000 series) instrument following the procedure of Martina et al., 1992. The accuracy of all major and trace elements are within the accuracy limits of $\pm 1 \%$.

\section{Results}

The calcareous substrate which has been assigned the early Pliocene age based on calcareous nannoplankton by Guptha et al., (2002) yielded eleven species of planktic foraminifera (Globigerina bulloides, Globigerinoides conglobatus, G. ruber, G. sacculifer, G. calida, Pulleniatina obliquiloculata, Sphaeroidinella dehiscens, Orbulina universa, Globorotalia menardii, G. scitula and Neogloboquadrina dutertrei) (Table -1) in variable abundance at different intervals of the substrate. Among them, N. dutertrei was the most abundant species (42.1\%) at 0-3 cm interval which sharply decreased in its abundance $(5.4 \%)$ at $5-7 \mathrm{~cm}$ interval, beyond which it was totally absent. On the other hand, G. menardii the only most dominant species found throughout the substrate, was sparsely distributed $(10.9 \%)$ at $0-3 \mathrm{cms}$ interval. Whereas, G. bulloides an ecologically important species and a proxy indicator of upwelling in the Indian Ocean (Prell and Curry, 1981) displayed increase in its abundance from 7-9 cm (1.75\%)to $13-15 \mathrm{~cm}(22.22 \%)$ intervals (Fig. 2). Among the other minor species, G. ruber was sparsely distributed except at 0-3 $\mathrm{cm}$ interval where it was showing highest abundance (21.2\%). $\delta 18 \mathrm{O}$ values on $\mathrm{G}$. menardii ranged between $-0.39 \%$ and $0.72 \%$ (Fig. 3). In addition to the above, plant and fungal (?)

spores were also encountered in intervals between 0-3 and 5-7 cm of which relatively higher number of them found to restrict to $0-3 \mathrm{cms}$ interval. The bulk chemical analyses of calcareous substrate indicated substantial increase in concentration of some trace metals (e.g. Ti, V, Co, Ni, $\mathrm{Cu}, \mathrm{Zn}, \mathrm{Ba}$ and $\mathrm{Sr}$ ) in the upper sections (e.g. 0-3 and 5- $7 \mathrm{~cm}$ intervals) of the substrate. The bulk mineralogy of calcareous substrate indicated predominance of calcite $(3.04 \AA)$ in x-ray diffractogram.

\section{Discussion}

Based on the calcareous nannoplankton assemblage, an early Pliocene age (3.7 Ma) was assigned to this calcareous substrate at VFZ by Guptha et al. (2002).By and large the forminiferal assemblage is comprised of solution resistant forms suggesting that the region of VFZ has experienced intense dissolution during the late Miocene to early Pliocene which is believed to 
have caused by strong biological productivity and subsequent $\mathrm{OMZ}$ as evidenced by the presence of Uvigerina, Lenticulina, Bulimina, and Bolivina as reported by Guptha et al., (2002). Milliman et al. (1999) documented added evidence to suggest considerable dissolution of calcium carbonate well above the chemical lysocline and concluded that the biological processes or biologically mediated processes were responsible for dissolution. The dominant calcite mineralogy (XRD peak at $3.04 \AA$ ) of the bulk carbonates from all intervals indicated that the substrate was deposited well above the calcite compensation depth (CCD) and the bulk carbonate was unaffected by the diagenetic process.

Abundant occurrence of a foraminiferal species $N$. dutertrei, an indicator of low salinity water (Cullen, 1981) at 0-3 cm interval which progressively decreased up to $5-7 \mathrm{~cm}$ interval is quite significant suggesting the prevalence of low saline water conditions analogous to the modern day Bay of Bengal in the northern Indian Ocean. As seen in the Bay of Bengal, the high production of N. dutertrei might have resulted largely due to nutrient supply by fresh water influx during monsoons (Guptha et al., 1997). Ittekkot et al., (1991) and Antoine et al. (1996) also reported nutrient supply by river discharge facilitating high average rates of primary productivity in the coastal areas in the Bay of Bengal. Besides, possibility of advection of nutrient rich waters from the upwelling regions of the northern Indian Ocean cannot be ruled out. This species has been reported in high productive areas during periods of strong chlorophyll maximum conditions following upwelling in San Pedro Basin, Southern California ( Sautter and Thunell. 1991), in the Bay of Bengal (Guptha, 1977) and in the Arabian Sea (Curry et al., 1992). Martinez et al., (1998) reported that the increased abundance of $N$. dutertrei away from well recognized upwelling regions was attributed to the brief periods of nutrient supplies by upwelling. This is further substantiated by the progressive decrease in $\delta 18 \mathrm{O}$ values (Fig. 3) indicate possible influence of freshwater as freshwater is characterized by lighter oxygen isotopic values than seawater and thus a large input of freshwater would have driven isotopic values down around this segment.

G. bulloides a proxy indicator of upwelling (Prell and Curry, 1981) in the Indian Ocean was sparsely distributed in the intervals between $0-3 \mathrm{~cm}$ and $7-9 \mathrm{~cm}$ indicating the prevalence of a weak upwelling. However, a progressive and significant increase in abundance of $G$. bulloides between $7-15 \mathrm{~cm}$ intervals reflected the change in hydrographic conditions led to open ocean upwelling. This is supported by the fact that similar situation prevailed in the Arabian Sea where Curry et al., (1992) reported foraminiferal flux dominated by G. bulloides suggesting the prevalence of intense upwelling during the Asian monsoons. The foraminiferal assemblage was dominated by resistant foraminifera such as $G$. conglobatus, P. obliquiloculata, S. dehiscens, G. menardii, G. scitula and N. dutertrei also substantiates restricted dissolution. Thus both benthic and planktic foraminifers displayed a close agreement in implying environmental conditions that 
led to OMZ.. Occurrence of a monsoon induced upwelling process and subsequent warm conditions was also supported as evidenced by the abundant occurrence of $G$. menardii throughout the calcareous substrate. Furthermore, it was believed that a very significant amounts of nutrients presumably supplied by freshwater caused by intense monsoons must have facilitated productivity.

The probable source of fresh water influx during the early Pliocene is believed to have been resulted by the strong Asian monsoon, which triggered a large scale physical and chemical weathering events in the Himalaya-Tibetan plateau (Filippelli, 1997). Eventually, it contributed enormous amount of terrigenous matter in the northern Indian Ocean thereby adding a large quantity of phosphorus in the water column which facilitated the biological productivity (Filippelli, 1997). During the Tertiary Period, biological productivity was variable in both time and space, with a sharp increase in productivity among the calcareous nannoplankton and planktic foraminifera of the early Pliocene which was a major event in the Indian Ocean (Siesser, 1995). Interestingly, Global Maps of Ocean Productivity by Berger (1989) also show that the VFZ falls in the present day primary productivity zone delineated by Dickens and Owen (1999). Zachos et al., (1993) opined that the increase in productivity was due to the re-organization of Paleogene circulation and climate controlled. But, Barron and Peterson (1991) found that the large changes in the circulation of the Indian Ocean occurred after the Eocene developing into the "modern" ocean circulation. Stronger global wind system as a result of global cooling intensified oceanic circulation resulting in greater mixing and upwelling in the Indian Ocean (Siesser, 1995). Imprints of post Miocene Himalayan erosion was reported based on isotopic and geochemical studies of ferromanganese crusts from the adjacent Central Indian Basin (Frank and O'Nions, 1998; O'Nions and Frank, 2000).

The phenomenon of influx of fresh water to this region at the time of formation of calcareous substrate is further evidenced by the presence of a large number of plant spores (unidentified, Fig. $4 \mathrm{a}-\mathrm{d}$ ), at 7-13 cm interval in association with the foraminifers. Apparently, these plant spores were of land derived which would have transported by fresh water influx. Alternatively, the transport of spores to the bottom of the deep ocean might have accomplished by wind during the intensification of monsoon. An evidence is available for widespread warm conditions on the earth surface during the mid Pliocene (Dowsett et al., 1999; Draut et al., 2003) and modeling studies indicated that surface wind strength over a large part of the earth were greater than today, implying that geostrophic gyre circulation may have been enhanced during the mid Pliocene (Haywood et al., 2000, 2002). Emeis et al. (1995), attributed the reported high productivity (for last $500 \mathrm{ka}$ ) in the Arabian Sea to stronger monsoon winds during interglacial times relative to glacial times. 
The bulk chemical analyses of calcareous substrate indicated a substantial increase in concentration of some trace metals (e.g. Ti, V, Co, Ni, Cu, $\mathrm{Zn}, \mathrm{Ba}$ and $\mathrm{Sr}$ ) in the upper sections (e.g. 0-3 and 5-7 cm intervals). The concentration of $\mathrm{Sr}$ in the top three sections (i.e. 0 to $7 \mathrm{~cm}$ intervals) varied between 898 and 1132 ppm (Table 2). Chester and Messiah - Hanna (1970) noted that $>80 \%$ of $\mathrm{Sr}$ in deep-sea sediments was held by calcareous material. High concentration of $\mathrm{Sr}$ in zooplankton and microplankton samples were also found to have higher concentration of $\mathrm{Cu}, \mathrm{Fe}, \mathrm{Zn}$ and $\mathrm{Ba}$ (Martin and Knauer, 1973), thus indicated absorption of these trace metals in their test during life cycle signatures of which were preserved in these microorganisms. This further indicated that at the time of sedimentation of the substrate material, many of the trace metals from the water column were transported to the sea floor by microorganisms. The abrupt increase in the concentration of these trace metals in the water column at the time of deposition of the calcareous matter is attributed to the surge of fresh water influx resulted by intensification of the Asian monsoon. The concentration of these trace metals must have been influenced by subsequent terrestrial input through large amount of chemical weathering during the early Pliocene.

Thus, it was inferred from this study that the biogenic components of the substrate was distinctly contributed by both the processes of upwelling and productivity triggered by a fresh water influx caused by the strong Asian monsoon during the early Pliocene. And subsequent erosion and deposition of terrestrial components originated from Himalaya-Tibetan plateau were also contributed significantly for the enhanced productivity.

\section{Acknowledgements}

The Director N.I.O. is thanked for permission to publish this work and Dr. S.M. Gupta for discussions. S/Shri U. Shirsat, A. Sardar, V. Khedekar and Miss Sonal Kamat are also thanked for their assistance in the sample preparation and SEM analyses. This work is partially funded by the US-India Fund through ONR (grant no. 0014-97-1-0925) (N.I.O. Project CLP 0886/COR0006) and D.S.T., New Delhi (grant no. ESS/23/VES/124/2001). Department of Ocean Development and the Captain and Crew of ORV Sagar Kanya are thanked for their continued support in this work. This is N.I.O. contribution \# 


\section{References:}

Berger, W.H., Leckie, R.M., Janecek, T.R., Stax, R. and Takayama, T., 1993. Neogene carbonate sedimentation on Ontong Java Plateau: Highlights and open questions. In: Proceedings of the Ocean Drilling Program, Scientific results: College Station, Texas, Ocean Drilling Program, 130: 711-744.

Bralower, T.J., Zachos, J.C., Thomas, E., Parrow, M. et al., 1995. Late Plaeocene to Eocene paleoceanography of the equatorial Pacific Ocean: Stable isotopes recorded at Ocean Drilling Program site 865, Alison Guyot. Paleoceanography, 10: 841-865.

Berger, W.H., 1989. Global Maps of Ocean Productivity. In: Berger, W.H., Smetacek, V.S. and Wefer, G. (eds). Productivity of the Ocean: Present and Past, John Wiley \& Sons Limited. 429-455.

Brummer, G.J.A. and Eijden, A.J.M.van. 1992. Blue-ocean" paleoproductivity estimates from pelagic carbonate mass accumulation rates. Mar. Micropaleontol., 19: 99-117.

Chester, R. and Messaiah-Hanna, R.G., 1970. Trace element partition patterns in North Atlantic deep-sea sediments, Geochim. Cosmochim. Acta, 34: 1121- 1128.

Cullen, J.L., 1981. Microfossil evidence for changing salinity patterns in the Bay of Bengal over the last 20,000 years, Palaeogeogr. Palaeoclimatol. Palaeoecol. 35: 315356.

Curry, W.B., Ostermann, D.R., Guptha,M.V.S., and Ittekkot, V., 1992. Foraminiferal production and monsoon upwelling in the Arabian Sea: Evidence from sediment traps, In: Summerhayes, C.P., Prell, W.L. and Emies, K.C. (eds). Upwelling Systems: Evolution since the Miocene: Geological Society Special Publication, 64: 93-106.

Draut, A.E., Raymo, M.E., McManus J.F. and Oppo, D.W., 2003. Climate stability during the Pliocene warm period, Paleoceanography, 18: 2-12.

Delaney, M.L. and Filippelli, G.M., 1994. An apparent contradiction in the role of phosphorus in Cenozoic chemical mass balances for the World Ocean. Paleoceanography, 9: 513-527.

Dickens, G.R. and Owen, R.M., 1994. Late Miocene-early Pliocene manganese redirection in the central Indian Ocean: Expansion of the intermediate water oxygen minimum zone. Paleoceanography, 9: 169-181.

Dickens, G.R. and Owen, R.M., 1996. Sediment geochemical evidence for an EarlyMiddle Gilbert (early Pliocene) productivity peak in the North Pacific Red Clay Province. Mar. Micropaleontol., 27: 107-120. 
Dickens, G.R. and Owen, R.M., 1999. The latest Miocene-early Pliocene biogenic bloom: a revised Indian Ocean perspective. Mar. Geol., 161: 75-91.

Dowsett, H.J., Barron, J.A., Poore, R.Z., Thompson, R.S., Cronin, T.M., Ishman, S.E., and Wilard, D.A., 1999. Middle Pliocene paleoenvironmental reconctruction: PRISM2, U.S. Geol. Surv., Open File Rep., U.S. Geol. Surv., Reston, Va., 99-535.

Emeis, K-C, Anderson, D.M., Doose, H., Kroon, D. and Schulz-Bull, D., 1995. Quaternary Research, 43: 355-361.

Emiliani, C., 1955. Pleistocene temperatures. J. Geology, 63: 538-578.

Farrell, J.W., Clemens, S.C. and Gromet, .LP. 1995a. Improved chronostratigraphic reference curve of the late Neogene seawater $87 \mathrm{Sr} / 86 \mathrm{Sr}$. Geology, 23: 403-407.

Farrell, J.W., Raffi, I., Janecek T.R., Murray, D.W., Levitan, M., Dadey, K.A., Emeis, K.C., Lyle, M., Flores, J.A. and Hovan, S., 1995b. Late Neogene sedimentation patterns in the eastern equatorial Pacific Ocean. In Proceedings of the Ocean Drilling Program, Scientific results, 138: 717-756.

Fillippelli, G.M., 1997. Intensification of the Asian monsoon and a chemical weathering event in the late Miocene-early Pliocene: Implications for late Neogene climatic change. Geology, 25:27-30.

Frank, M., and O'Nions, R.K., 1998. Sources of Pb for Indian ocean ferromanganese crusts: a record of Himalayan erosion. Earth and Planet. Sci. Lett., 158: 121-130.

Grassl, H., Jost, V., Schulz, J., Ramesh Kumar, M.R., Bauer, P., and Schluessel, P., 2000. The Hamburg ocean-atmosphere parameters and fluxes from satellite data (HOAPS): A climatological atlas of satellite-derived air-sea-interaction parameters over the world oceans. Max-Planck-Institute fur Meteorologie, report no. 312, 130 pp.

Gupta, A.K., and Thomas, E., 1999. Latest Miocene-Pleistocene productivity and deep sea ventilation in the northwestern Indian Ocean (Deep Sea Drilling Project Site 219). Paleoceanography, 14: 62-73.

Guptha, M.V.S., Currry, W.B., Ittekkot, V. and Muralinath, A.S., 1997. Seasonal variation in the flux of planktonic Foraminifera: Sediment trap results from the Bay of Bengal Northern Indian Ocean. J. Foraminiferal Res., 27: 5-19.

Guptha, M.V.S., Ranadip Banerjee and Lina Mergulhao, 2002. On the nature of the calcareous substrate of a ferromanganese crust from the Vityaz Fracture Zone, Central Indian Ridge: inferences on paleoceanography. Geo-Mar. Lett., 22: 12-18.

Haywood, A.M., Sellwood, B.W. and Valdes, P.J., 2000. Regional warming: Pliocene (3 $\mathrm{Ma}$ ) plaeoclimate of Europe and the Mediterranean, Geology, 28: 1063-1066. 
Haywood, A.M., Valdes, P.J. and Sellwood, B.W., 2002. Magnitude of climate variability during middle Pliocene warmth: A paleoclimate modeling study, Palaeogeogr. Palaeoclimatol. Palaeoecol., 188: 1-24.

Hermoyian, C.S. and Owen, R.M., 2001. Late Miocene - early Pliocene biogenic bloom: Evidence from low productivity region of the Indian and Atlantic oceans.

Paleoceanography, 16(1): 95-100.

Ittekkot V., Nair R. R., Honjo S., Ramaswamy V., Bartsch M., Manganini S., and Desai B. N., 1991. Enhanced particle fluxes in Bay of Bengal induced by injection of fresh water. Nature, 351: 385-387.

Martin, J.H. and Knauer, G.A., 1973. The elemental composition of pklankton. Geochim. Cosmochim. Acta, 37: 1639-1653.

Martina, T., Jarvis, I. and Jarvis, K.E., 1992. An assessment of dissolution techniques for the analysis of geological samples by plasma spectrometry. Chem. Geol., 95: 35-62.

Nair, R.R., Ittekot, V., Manganini, S.J., Ramaswamy, V., Hakke, B., Degens, E.T., Desai, B.N. and Honjo, S., 1989. Increased particle flux to the deep ocean related to monsoons. Nature 338 (no. 6218): 749-751.

O’Nions, R.K. and Frank, M., 2000. Long term records of erosional change from marine ferromanganese crusts.- Proc. Indian Acad. Sci. (Earth Planet. Sci.), 109: 171-180.

Peterson, L.C. and Backman, J., 1990. Late Cenozoic carbonate accumulation and the history of the carbonate compensation depth in the western equatorial Indian Ocean. in Proceedings of the Ocean Drilling Program, Scientific results, 115: 467-507.

Peterson, L.C., Murray, D.W., Ehrmann, W.U. and Hempel, P., 1992. Cenozoic carbonate accumulation and compensation depth changes in the Indian Ocean. In: Duncan RA, Rea DK, Kidd RB, Von Rad U, Weissel JK (eds) Synthesis of results from scientific drilling in the Indian Ocean. Am. Geophys. Union Geophys. Monogr. 70: 311333.

Prell, W.L., and Curry, W.B., 1981. Faunal and isotopic indices of monsoonal upwelling, Western Arabian Sea: Oceanologica Acta, 4: 91-98.

Prell, W.L., et al., (1991) Proceedings of the Ocean Drilling Program: Sci. Results. 117, 1236.

Raymo, M.E. and Ruddiman, W.F., 1992. Tectonic forcing of late Cenozoic climate. Nature, 359: 117-122. 
Rea, D.K., Basov, I. A. and Krissek, L.A., 1995. Scientific results of drilling the North Pacific transect. In Proceedings of the Ocean Drilling Program, Scientific results: College Station, Texas, Ocean Drilling Program, 145:577-596.

Rea, D.K., 1992. Delivery of Himalayan sediment to the northern Indian Ocean and its Relation to global climate, sea level, uplift and sea water strontium. Synthesis of Results from Scientific Drilling in the Indian Ocean, Geophys. Monogr. Duncan, R. and Rea D.K. (eds). 70: 387-402, AGU, Washington, D.C.

Siesser, W.G., 1995. Paleoproductivity of the Indian Ocean during Tertiary Period. Global Planet. Change, 11: 71-88.

Thunell, R.C., and Sautter, L.R., 1992. Planktic foraminiferal faunal and stable isotopic indices of upwelling: a sediment trap study in the San Pedro Basin, Southern California Bight, In Summerhayes, C. P., Prell, W.L., and Emeis, K.C. (eds.), Upwelling Systems: Evolution since the Miocene. Geol. Soc. Spl. Publ., 64: 77-91.

Vincent, E., 1974. Cenozoic Planktonic biostratigraphy and paleoceanography of the tropical western Indian ocean, DSDP Leg 24, in Initial Report of the DSDP, Washington, DC, U.S. Govt. printing press 24: 1111-1150.

Wyrtki K., 1971. Oceanographic Atlas of the International Indian Ocean Expedition.Washington DC: National Science Foundation. pp. 531.

About the first author

Dr. MVS Guptha was a Senior Micropaleontologist who has been associated with the National Institute of Oceanography, Dona Paula, Goa for over three and a half decades. Presently, he is engaged with the writing of a book on Calcareous nannoplankton from the Northern Indian Ocean sponsored by the Department of Science \& Technology, Govt. of India. Besides, he has been actively associated with many national and international research projects in the Indian Ocean related to paleoceanography. Dr. Guptha has published several scientific papers in reputed international journals. 


\section{List of figures}

Fig. 1. Map showing the study area.

Fig. 2. Graphical representation of the abundance percentages of the various planktic foraminiferal species at different depth intervals of the calcareous substrate.

Fig. 3. $\delta 18 \mathrm{O}$ values of $G$. menardi at different depth intervals of the calcareous substrate. The dotted line indicate the boundary between the higher values for colder and lower values for warmer period.

Fig. 4. (a-d) SEM photographs of different plant and fungal (?)spores (unidentified)

List of Tables:

Table 1:

Variable abundance (\%) of different species of planktic foraminfers at different depth intervals of the calcareous substrate.

Table 2:

Major and trace element concentrations of bulk carbonate at different depth intervals of the calcareous substrate. 
Table 1.

Variable abundance (\%) of different species of planktic foraminfers at different depth intervals of the calcareous substrate.

\begin{tabular}{|l|l|l|l|l|l|l|l|}
\hline Species name & $\mathbf{0 - 3} \mathbf{~ c m}$ & $\mathbf{3 - 5} \mathbf{~ c m}$ & $\mathbf{5 - 7} \mathbf{~ c m}$ & $\mathbf{7 - 9} \mathbf{~ c m}$ & $\begin{array}{l}\mathbf{9 - 1 1} \\
\mathbf{c m}\end{array}$ & $\begin{array}{l}\mathbf{1 1 - 1 3} \\
\mathbf{c m}\end{array}$ & $\begin{array}{l}\mathbf{1 3 - 1 5} \\
\mathbf{c m}\end{array}$ \\
\hline $\begin{array}{l}\text { Globigerina } \\
\text { bulloides }\end{array}$ & 3.43 & 2.94 & 3.13 & 1.75 & 8.44 & 12.27 & 22.22 \\
\hline $\begin{array}{l}\text { Globigerinoides } \\
\text { conglobatus }\end{array}$ & 0.93 & 11.56 & 4.07 & 5.26 & 2.25 & 2.45 & 11.67 \\
\hline $\begin{array}{l}\text { Globigerinoides } \\
\text { ruber }\end{array}$ & 21.18 & 4.62 & 2.68 & 6.14 & 6.33 & 4.91 & 2.22 \\
\hline $\begin{array}{l}\text { Globigerinoides } \\
\text { sacculifer }\end{array}$ & n.d. & n.d. & 2.68 & 0.44 & 0.42 & n.d. & n.d. \\
\hline $\begin{array}{l}\text { Globigerinoides } \\
\text { calida }\end{array}$ & 7.17 & 1.73 & 3.57 & 4.39 & 7.02 & 2.45 & 3.33 \\
\hline $\begin{array}{l}\text { Pulleniatina } \\
\text { obliquiloculata }\end{array}$ & 5.92 & 3.47 & 2.23 & n.d. & 2.11 & n.d. & n.d. \\
\hline $\begin{array}{l}\text { Sphaeroidinella } \\
\text { dehiscens }\end{array}$ & 3.43 & 5.78 & 11.61 & 14.91 & 10.55 & 11.04 & 11.11 \\
\hline Orbulina universa & n.d. & 4.07 & 2.23 & 2.19 & 2.95 & 1.23 & 2.78 \\
\hline $\begin{array}{l}\text { Globorotalia } \\
\text { menardii }\end{array}$ & 10.90 & 40.46 & 58.48 & 47.37 & 53.54 & 59.51 & 36.67 \\
\hline $\begin{array}{l}\text { Globorotalia } \\
\text { scitula }\end{array}$ & 3.74 & 2.89 & 1.34 & 17.54 & 5.49 & 6.13 & 5.56 \\
\hline $\begin{array}{l}\text { Neogloboquadrina } \\
\text { dutertrei }\end{array}$ & 42.06 & 19.07 & 5.36 & n.d. & n.d. & n.d. & n.d. \\
\hline
\end{tabular}

n.d. $=$ not detected

Table 2.

Major and trace element concentrations of bulk carbonate at different depth intervals of the calcareous substrate.

\begin{tabular}{|l|l|l|l|l|l|l|l|l|l|l|l|l|l|l|}
\hline $\begin{array}{l}\text { Sample } \\
\text { depth } \\
\text { interval }\end{array}$ & $\begin{array}{l}\mathrm{Al} \\
(\%)\end{array}$ & $\begin{array}{l}\mathrm{Fe} \\
(\%)\end{array}$ & $\begin{array}{l}\mathrm{Mn} \\
(\%)\end{array}$ & $\begin{array}{l}\mathrm{Ca} \\
(\%)\end{array}$ & $\begin{array}{l}\mathrm{Mg} \\
(\%)\end{array}$ & $\begin{array}{l}\mathrm{Ti} \\
(\%)\end{array}$ & $\begin{array}{l}\mathrm{Cr} \\
(\mathrm{ppm})\end{array}$ & $\begin{array}{l}\mathrm{V} \\
(\mathrm{ppm})\end{array}$ & $\begin{array}{l}\mathrm{Co} \\
(\mathrm{ppm})\end{array}$ & $\begin{array}{l}\mathrm{Ni} \\
(\mathrm{ppm})\end{array}$ & $\begin{array}{l}\mathrm{Cu} \\
(\mathrm{ppm})\end{array}$ & $\begin{array}{l}\mathrm{Zn} \\
(\mathrm{ppm})\end{array}$ & $\begin{array}{l}\mathrm{Ba} \\
(\mathrm{ppm})\end{array}$ & $\begin{array}{l}\mathrm{Sr} \\
(\mathrm{ppm})\end{array}$ \\
\hline $0-3 \mathrm{~cm}$ & 1.24 & 3.13 & 1.0 & 29.93 & 0.51 & 0.11 & 17 & 69 & 164 & 117 & 177 & 52 & 147 & 1132 \\
\hline $3-5 \mathrm{~cm}$ & 1.34 & 0.94 & 0.15 & 31.52 & 0.54 & 0.06 & 32 & 20 & 22 & 41 & 48 & 20 & 45 & 968 \\
\hline $5-7 \mathrm{~cm}$ & 1.39 & 2.59 & 1.19 & 29.23 & 0.78 & 0.11 & 38 & 61 & 192 & 119 & 142 & 42 & 122 & 898 \\
\hline $7-9 \mathrm{~cm}$ & 1.67 & 1.44 & 0.29 & 32.24 & 0.91 & 0.08 & 62 & 31 & 50 & 54 & 66 & 25 & 45 & 870 \\
\hline $9-11 \mathrm{~cm}$ & 1.61 & 1.03 & 0.08 & 33.01 & 0.83 & 0.07 & 56 & 21 & 16 & 29 & 39 & 17 & 22 & 939 \\
\hline $11-13 \mathrm{~cm}$ & 1.63 & 1.08 & 0.12 & 33.27 & 0.93 & 0.08 & 67 & 25 & 27 & 33 & 46 & 19 & 23 & 880 \\
\hline $13-15 \mathrm{~cm}$ & 1.45 & 0.80 & 0.04 & 33.61 & 0.81 & 0.07 & 54 & 16 & 9 & 23 & 36 & 22 & 14 & 896 \\
\hline
\end{tabular}




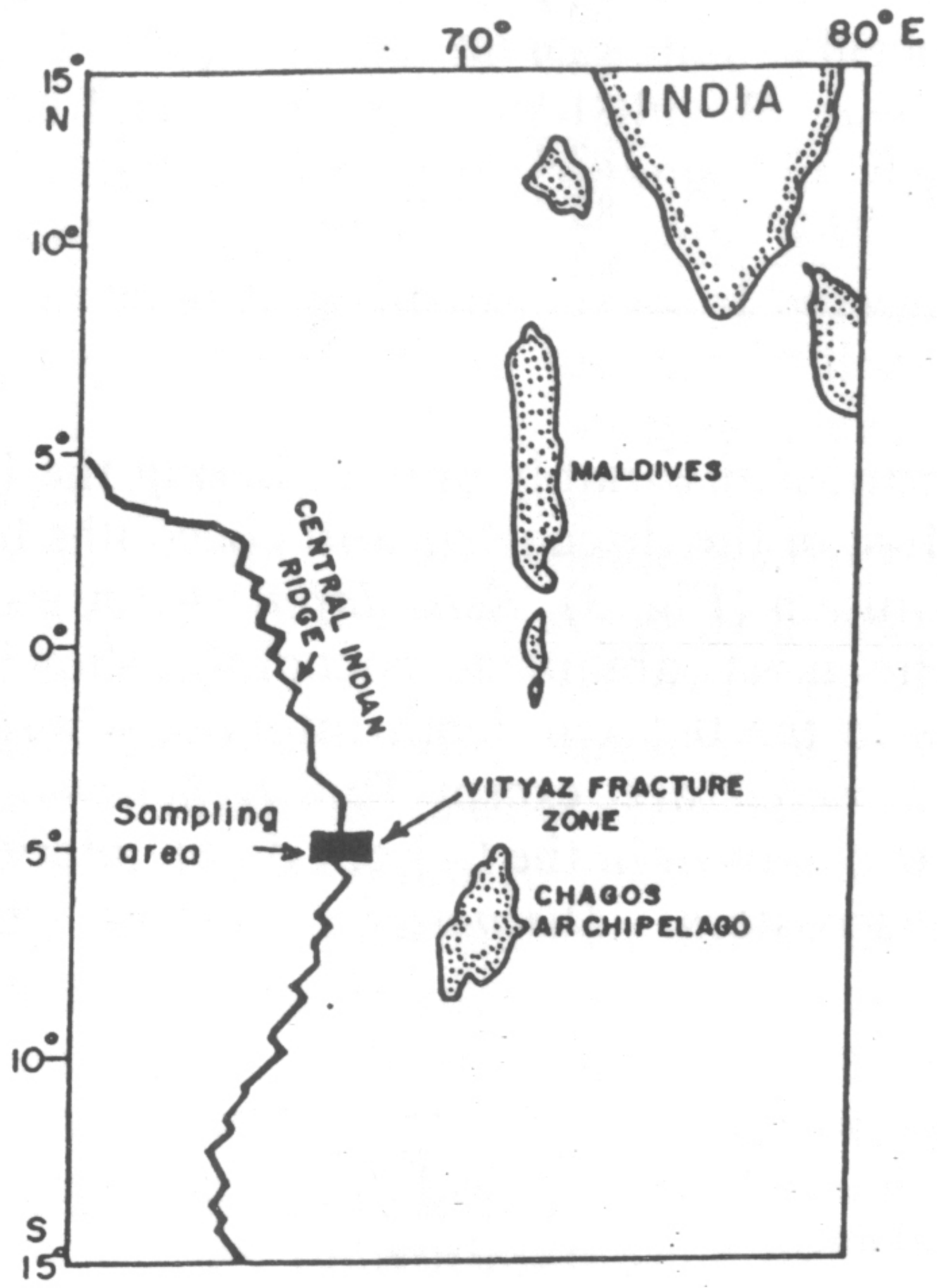

Fig. 1 


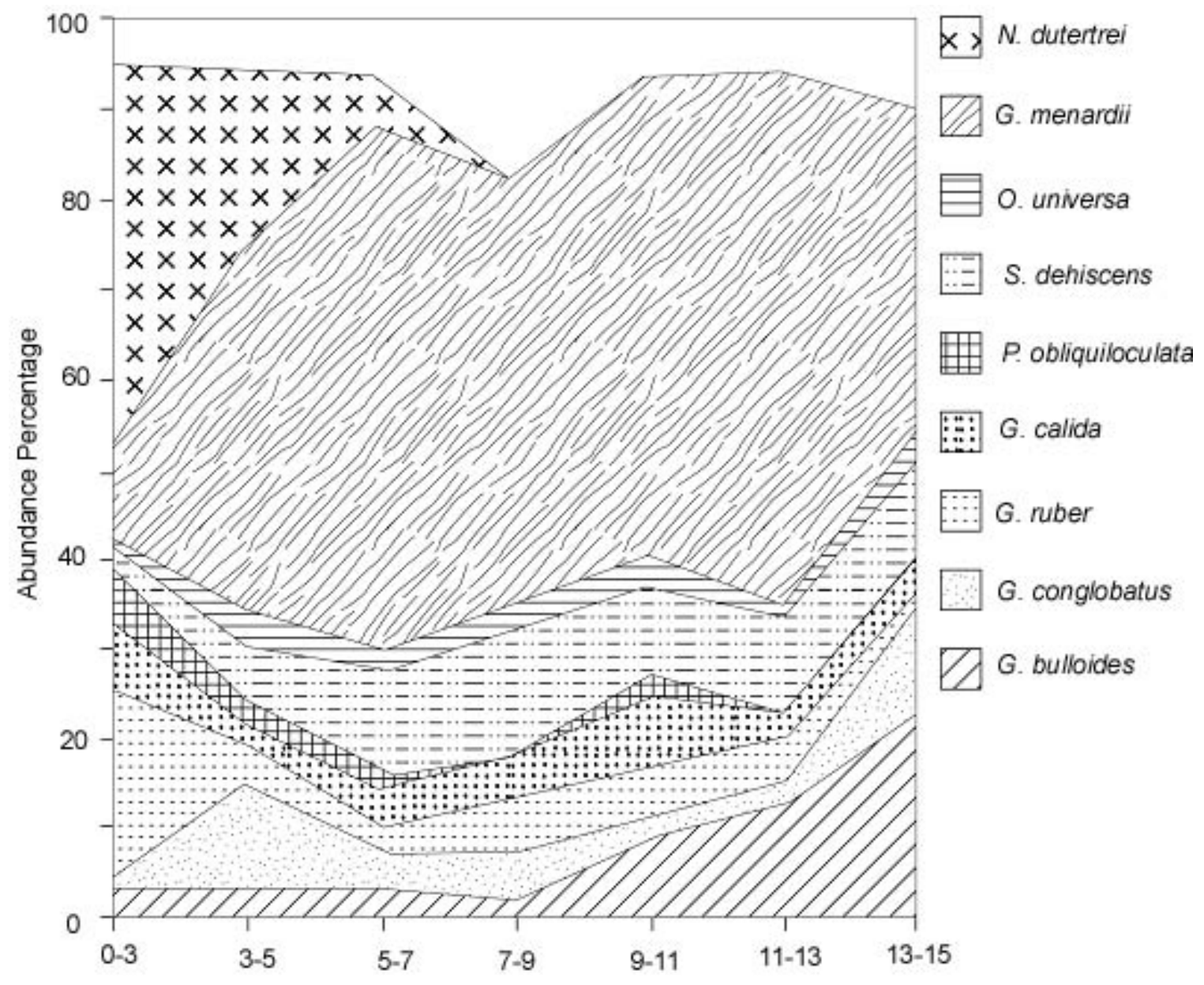

Fig. 2 


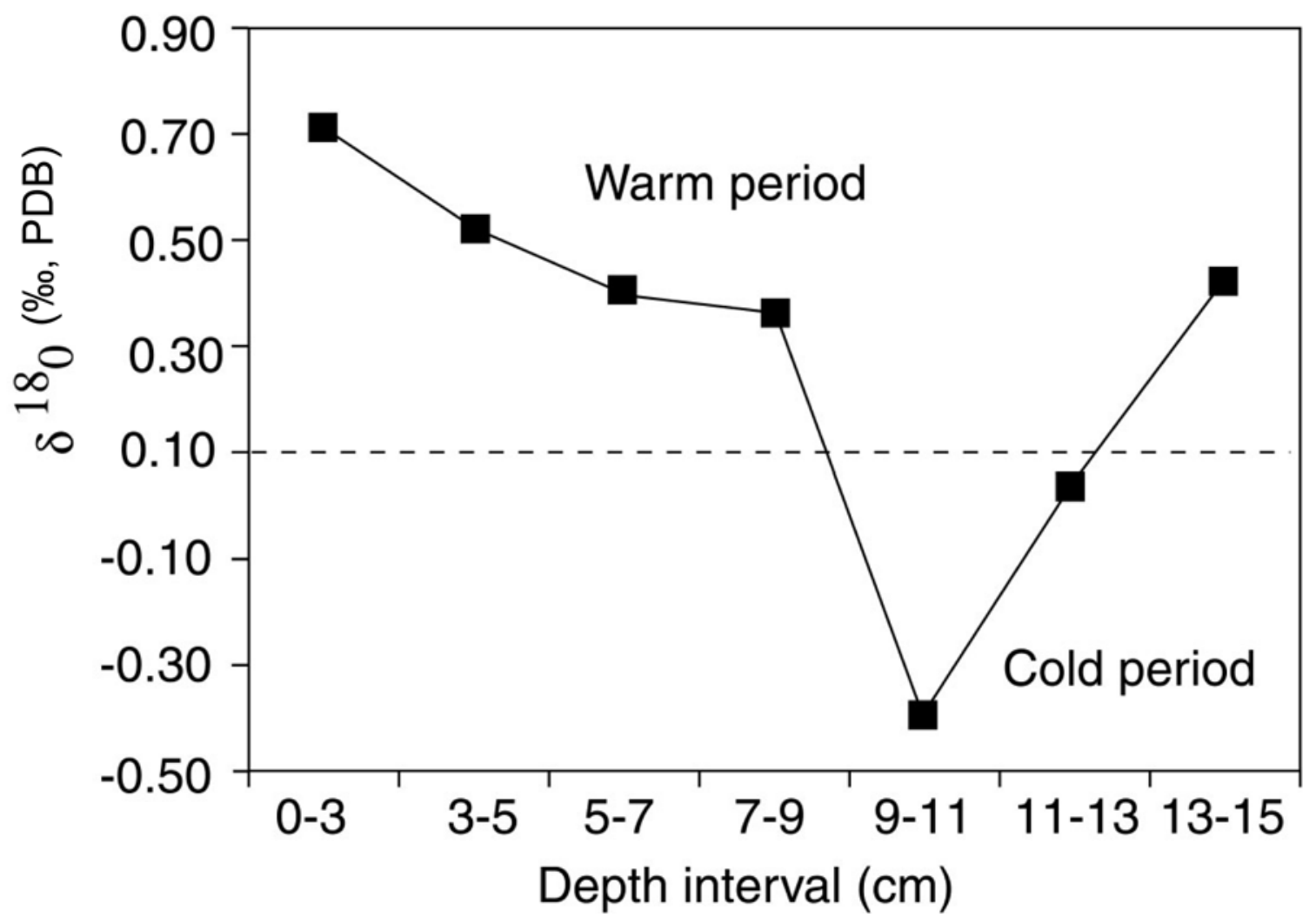

Fig. 3 

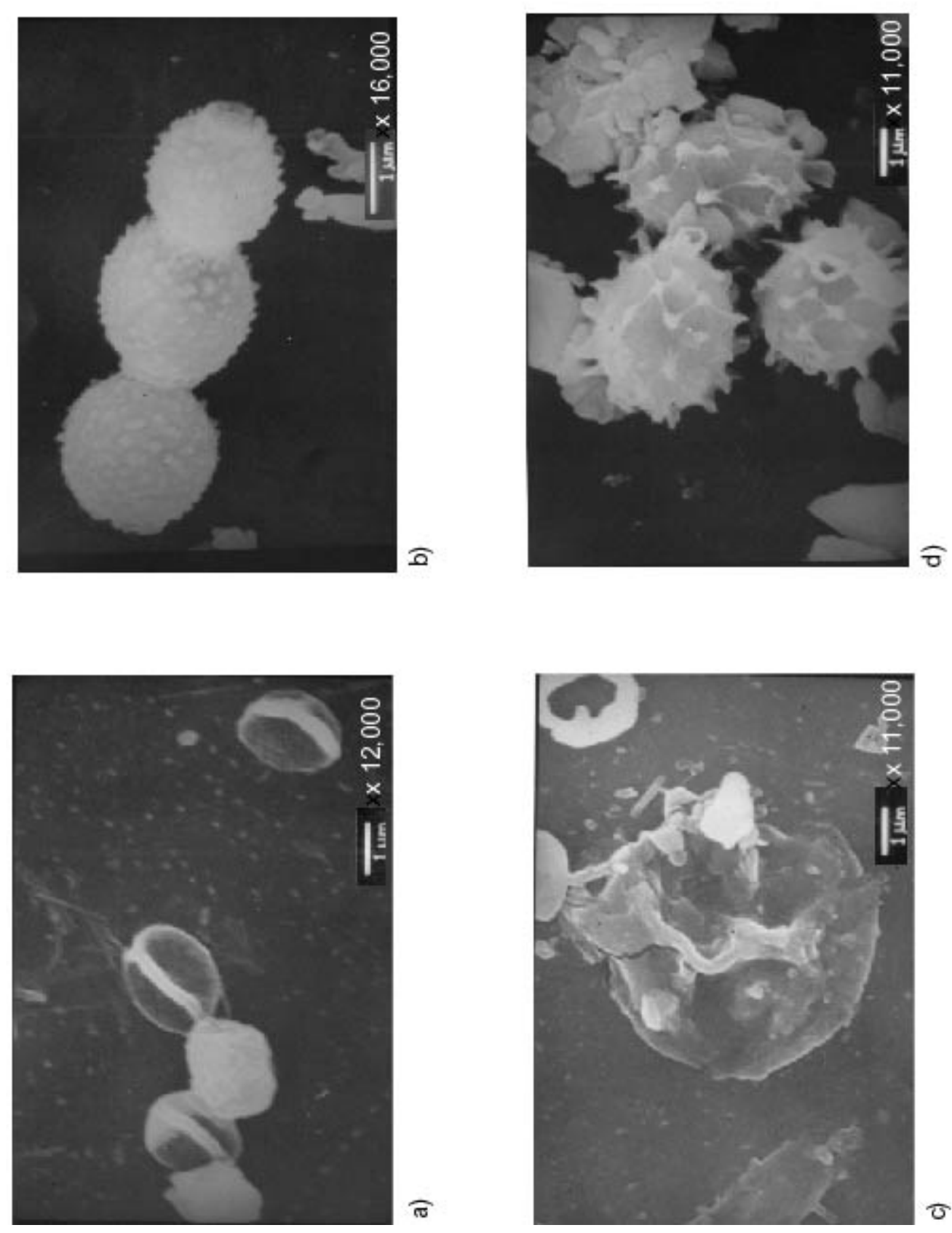

Fig. 4 
